\title{
CATATAN BARU DAN KEANEKARAGAMAN KOPEPODA DI PERAIRAN PANTAI DAN MANGROVE PULAU PANAITAN, TAMAN NASIONAL UJUNG KULON, BANTEN
}

\section{NEW RECORD AND DIVERSITY OF COPEPODA IN COASTAL AND MANGROVE AREA OF PANAITAN ISLAND, UJUNG KULON NATIONAL PARK, BANTEN}

\author{
Mulyadi, Rena Tri Hernawati, Ujang Nurhaman \\ Museum Zoologicum Bogoriense, Pusat Penelitian Biologi-LIPI \\ Gedung Widyasatwaloka, Jl. Raya Bogor KM. 46, Cibinong, Bogor, Jawa Barat \\ E-mail:mulyadi-08@yahoo.com
}

(diterima Januari 2021, direvisi April 2021, disetujui Juli 2021)

\begin{abstract}
ABSTRAK
Observasi tentang keragaman, kelimpahan, dan sebaran kopepoda di perairan pantai dan mangrove di Pulau Panaitan dilakukan pada bulan November 2008 (musim hujan). Sampel kopepoda diambil dengan jaring plankton secara horizontal dan vertikal pada siang dan malam hari, kemudian disimpan dan diidentifikasi di MZB LIPI. Penelitian ini bertujuan untuk mengukur keanekaragaman dan kelimpahan kopepoda di musim hujan yang mempunyai suhu dan salinitas tertentu. Ditemukan 72 jenis kopepoda dari 37 marga, 24 suku, dari enam bangsa termasuk dua catatan baru, yaitu Pontella forficula dan Pseudodiaptomus incisester. Keanekaragaman kopepoda di pantai dan mangrove tinggi sekitar 0,9473 dan 0,8345 (rentang 0-1). Akan tetapi, jika keduanya dibandingkan maka keanekaragaman kopepoda di pantai lebih tinggi dibandingkan di mangrove $(3,584$ vs. 2,431). Pontella denticauda dan Temora discaudata yang merupakan tipe neritik ditemukan mendominasi perairan pantai, sedangkan Corycaeus speciosus dan Oncaea conifera yang merupakan tipe neritik mendominasi perairan mangrove. Dominasi jenis oleh kopepoda neritik terjadi karena perairan Pulau Panaitan bersalinitas tinggi dan bersuhu rendah.
\end{abstract}

Kata kunci: Kopepoda neritik, salinitas, suhu, teknik horizontal, teknik vertikal.

\begin{abstract}
Observations on the diversity of Copepoda, abundance, and distribution in mangrove and coastal area in Panaitan Island, Ujung Kulon National Park, Banten were conducted in November 2008 (rainy season). Copepod samples were taken from along Panaitan Strait using horizontal and vertical plankton nets, day and night, then preserved, identified and deposited in MZB LIPI. This study aimed to estimate the diversity and abundance of Copepoda at certain salinity and temperature in the rainy season. Seventy-two Copepoda were found from 37 genera, 24 families and six orders, including two new records namely Pontella forficula and Pseudodiaptomus incisester. Copepoda diversities in mangrove and coastal are high approximately 0,9473 and 0,8345 (in range 0-1). However, if both habitats were compared, Copepoda diversity in coastal area is higher than in mangrove area (3,584 vs. 2,431). Pontella denticauda (N) and Temora discaudata are neritic species dominating coastal area, whereas Corycaeus speciosus and Oncaea conifera are neritic species dominating mangrove area. Panaitan Island's marine is dominated by neritic copepods because having high salinity and low temperature.
\end{abstract}

Keywords: Horizontal technique, neritic copepoda, salinity, temperature, vertical technique.

\section{PENDAHULUAN}

Panaitan $\left(105^{\circ} 4^{\prime}-105^{\circ} 14^{\prime}\right.$ BT dan $6^{\circ}$ $32^{\prime}-6^{\circ} 40^{\prime}$ LS) adalah pulau vulkanik yang terletak di Selat Sunda, antara Jawa dan Sumatra. Pulau seluas 17.500 ha ini adalah bagian dari Taman Nasional Ujung Kulon (TNUK), Pandeglang, Banten. Di bagian timur pulau terdapat empat lokasi hutan mangrove, yaitu Legon Mandar, Legon Kadam, Legon Lentah, dan Buntu.
Kopepoda berperan penting dalam kehidupan akuatik karena berfungsi sebagai konsumen primer dan penghubung antara fitoplankton dan tingkat trofik yang lebih tinggi. Kopepoda mendominasi hingga 70 $90 \%$ dari populasi zooplankton di lautan dan merupakan sumber pakan utama bagi semua jenis ikan pelagis (Nybaken 1982). Banyaknya kopepoda di suatu perairan mengindikasikan bahwa lokasi tersebut ideal sebagai tempat 
pemijahan dan asuhan bagi berbagai organisme air. Kelimpahan dan sebarannya dipengaruhi oleh faktor fisika, kimia, dan biologi perairan seperti suhu, salinitas, dan ketersediaan pakan sehingga kelimpahannya sangat fluktuatif menurut musim dan lokasi, serta dapat dikaitkan dengan kesuburan perairan.

Penelitian tentang taksonomi dan ekologi kopepoda di perairan mangrove di Indonesia telah banyak dilakukan. Dussart (1986) mendeskripsikan jenis baru Acartiella nicolae dari perairan mangrove Sungai Mahakam. Mulyadi \& Ishimaru (1994) melaporkan 55 jenis termasuk 19 jenis catatan baru kopepoda dari perairan mangrove Segara Anakan, Cilacap, dan dari lokasi yang sama Mulyadi (1997; 2003) mendeskripsi dua jenis baru Labidocera muranoi dan Pontella kleini. Sedangkan Yuniar dkk. (2007) melaporkan tentang Kopepoda parasit pada delapan jenis ikan komersial penting di Segara Anakan, yaitu Caligus acanthopagri, C. pipsoni, Cyamatoa sp., Argasilus sp., Neobrachia cf. polynemi, Nothomolacus sp., Parapetalus hirsutus, Peniculus cf. scomberi, dan Pseudocaligus sp. Hasil penelitian tahun 2009 menunjukan adanya penurunan keragaman jenis kopepoda di perairan ini, hanya ditemukan 34 jenis dari 23 marga dan 17 suku (Mulyadi \& Murniati 2017). Keragaman jenis kopepoda juga dilaporkan oleh Nurdin dkk. (1998) di muara Sungai Rokan, Riau, muara Sungai Mempawah, Pontianak (Rahayu dkk. 2013), dan laguna Glagah, Kulon Progo (Saputra dkk. 2012).

Tulisan ini membahas tentang sebaran, keanekaragaman, dan kelimpahan jenis kopepoda di perairan mangrove Pulau Panaitan dan perairan Selat Panaitan, serta kaitan dominansi jenis dengan faktor lingkungan, yaitu suhu dan salinitas. Informasi tentang struktur komunitas kopepoda diharapkan dapat dijadikan sebagai bahan pertimbangan dalam pengelolaan ekosistem mangrove dan pantai di Pulau Panaitan pada masa mendatang karena kehadiran kopepoda sangat menentukan keberlangsungan populasi ikan di perairan tersebut. Pengelolaan yang baik akan mengembalikan fungsi perairan mangrove sebagai tempat mencari makan, pemeliharaan juvenil, dan tempat berlindung bagi berbagai jenis biota akuatik.

\section{METODE PENELITIAN}

Pengambilan sampel kopepoda dilakukan pada bulan November 2008 (musim hujan) di dua lokasi, yakni perairan mangrove di Legon Mandar, Legon Kadam, Legon Lentah dan Buntu, serta perairan pelagis Selat Panaitan. Teknik pengambilan sampel secara horizontal dan vertikal dilakukan di titik-titik lokasi Selat Panaitan dan di mangrove Legon Lentah, sedangkan habitat mangrove lainnya hanya menggunakan teknik horizontal dengan metode penyaringan 100 liter air karena keadaan lingkungan hutan mangrove yang tipis atau rusak, dangkal, dan berlumpur sehingga tidak memungkinkan untuk menerapkan teknik vertikal. Di setiap lokasi ditetapkan tiga stasiun sebagai tempat pengambilan sampel dengan jarak antara stasiun 100 m (Gambar 1). Pengambilan sampel di masing-masing stasiun dilakukan dengan ulangan lima kali. Sampel Kopepoda diambil dengan cara menarik jaring plankton (diameter mulut jaring $45 \mathrm{~cm}$ dan ukuran mata jaring $0.33 \mathrm{~mm}$ ) secara horizontal selama lima menit dengan perahu motor berkecepatan rendah (2 knot), dan pengambilan secara vertikal pada kedalaman 10-25 m. Di bagian tengah mulut jaring dipasang flowmeter untuk mengetahui volume air yang tersaring. Sampel yang 


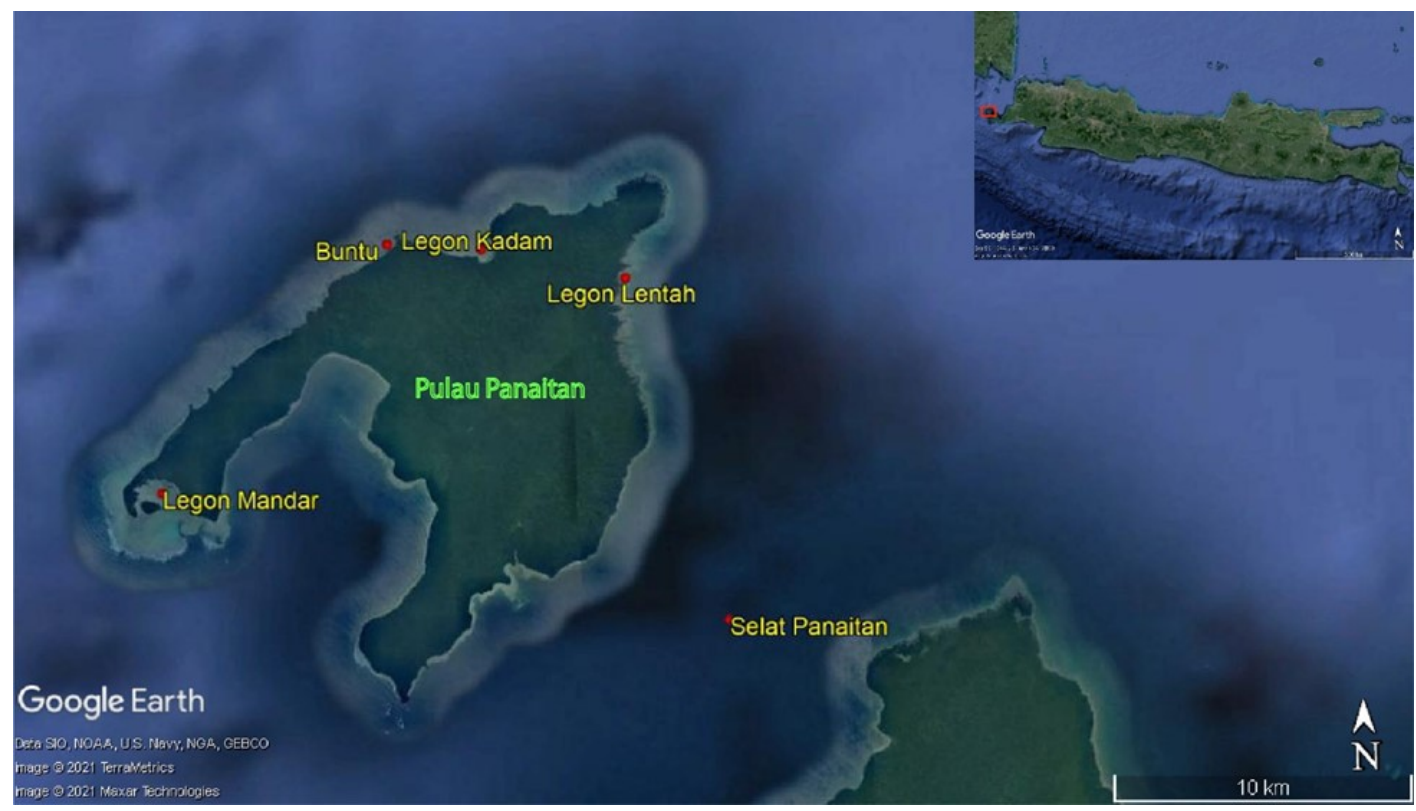

Gambar 1. Lokasi dan stasiun pengamatan Kopepoda di Pulau Panaitan, Banten.

diperoleh diawetkan dengan larutan formalin

4\%. Bersamaan dengan pengambilan sampel kopepoda, dilakukan juga pengukuran suhu dan salinitas perairan dengan menggunakan termometer dan salinometer Sato Shouji YSI 33M S-T Meter. Salinitas air digunakan sebagai dasar pengelompokan Kopepoda (Mulyadi \& Ishimaru 1994).

Penyortiran dan perhitungan kelimpahan spesimen Kopepoda dari zooplankton lain dan detritus dilakukan dibawah mikroskop stereo. Spesimen yang diidentifikasi diambil dari botol sampel dengan pinset mikro, lalu diletakkan di atas kaca objek cekung yang telah diberi campuran larutan gliserin-akuades dan pewarna methylene blue. Seluruh Kopepoda dalam sampel diidentifikasi hingga tingkat jenis berdasarkan panduan Scott (1909), Mori (1937), Huys \& Boxshall (1991), dan Mulyadi (1997; 2002; 2004), lalu dihitung jumlah individunya berdasarkan jenis kelamin dan tingkat stadianya betina $=\mathrm{b}$, jantan $=\mathrm{j}$, dan anakan $=a$. Kopepoda yang telah diidentifikasi dimasukkan ke dalam botol vial berlabel dengan pengawet alkohol $70 \%$ dan disimpan di Museum Zoologi Bogor (MZB), Pusat Penelitian Biologi LIPI, Cibinong sebagai koleksi acuan.

Data kelimpahan dan perolehan jenis dianalisis menggunakan software Past 4.01 (Hammer et al. 2001). Indeks Shannon (Shannon 1948) dan indeks Simpson (Simpson 1949) dihitung untuk mengukur tingkat keanekaragaman jenis. Indeks Shannon (entropi) digunakan untuk membandingkan keanekaragaman di dua habitat berbeda. Indeks Shannon biasanya mengukur ketidakpastian. Ketidakpastian yang tinggi akan mengindikasikan keanekaragaman yang tinggi sehingga perlu indeks keanekaragaman lain sebagai pembanding. Indeks Simpson =1-D menghitung keanekaragaman berdasarkan dominansi di area dan nilainya berkisar 0 sampai 1 , makin besar nilai makin besar keanekaragaman sampel. Dominansi = 1-Indeks Simpson, berkisar antara 0 (semua taksa sama-sama ada) sampai 1 (satu taksa mendominansi komunitas secara penuh). Indeks Kemerataan (Evenness_eH/S) (Buzas \& Gibson 1969) merupakan distribusi 


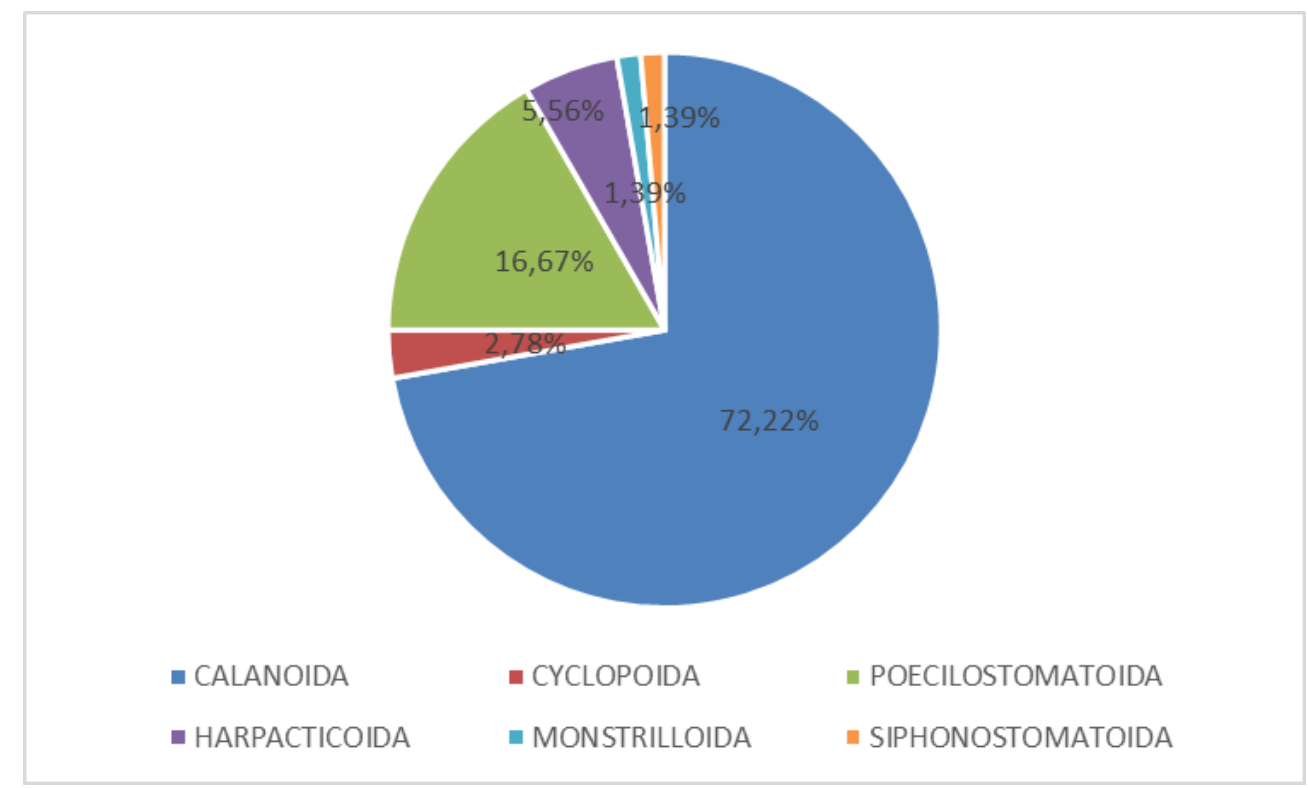

Gambar 2. Persentase ordo kopepoda di Pulau Panaitan dalam \%.

individu-individu di antara jenis yang berbeda. Analisis Chao-1 (Chao 1984) digunakan untuk mengestimasi total kekayaan jenis berdasarkan data kelimpahan dan dapat mengevaluasi upaya sampling pada penelitian ini.

\section{HASIL DAN PEMBAHASAN}

\section{Catatan Baru Distribusi Jenis Kopepoda}

Total sebanyak 72 jenis kopepoda yang termasuk dalam 36 marga dari 23 suku dan 6 ordo ditemukan di dua lokasi pantai dan mangrove pada saat musim hujan (Tabel 1). Calanoida merupakan ordo yang paling banyak ditemukan dengan 52 jenis dari 25 marga dan 15 suku (72,22\%), diikuti oleh Poecilostomatoida $(16,67 \%, 12$ jenis dari 5 marga dan 3 suku), Harpacticoida (5,55\%, 4 jenis dari 4 marga dan 3 suku), Cyclopoida $(2,78 \%, 2$ jenis, 1 marga dan 1 suku), sedangkan dari ordo Siphonostomatoida dan Monstrilloida masing-masing hanya diwakili satu jenis (1,39\%) (Gambar 2; 52 jenis dan 12 jenis). Ordo Calanoida dan Poecilostromatoida merupakan jenis kopepoda berukuran relatif lebih besar dan umumnya hidup di perairan yang tidak dipengaruhi daratan, seperti yang banyak ditemukan di Laut Jawa (Mulyadi, 2004).

Berdasarkan sebaran geografisnya, 45 jenis kopepoda yang ditemukan adalah tipe Indo-Pasifik, 22 jenis cosmopolitan, dua jenis (Pontella forficula dan Pseudodiaptomus incises) merupakan catatan baru yang sebelumnya dilaporkan endemik untuk perairan Filipina dan Laut China, sedangkan 3 jenis lainnya, Sapphirina sp., Monstrilla sp., dan Caligus sp. belum bisa diidentifikasi sampai tingkat jenis karena merupakan jenis baru dan akan dideskripsi pada tulisan mendatang.

Ditinjau dari kemampuan toleransi terhadap salinitas, jenis kopepoda dapat dibagi menjadi plankton oseanik, neritikoseanik, neritik, dan estuarin-neritik (Kim 1985; Madhupratap \& Haridas 1986). Kopepoda yang dikoleksi secara horizontal di Pulau Panaitan terdiri dari 41 jenis neritik, 16 jenis oseanik, 9 jenis neritik-oseanik, 4 jenis estuarinneritik, dan ada 2 jenis yang bersifat parasit (Tabel 1). 
Tabel 1. Daftar jenis dan kelimpahan Kopepoda yang ditemukan di perairan pantai dan mangrove Pulau Panaitan pada musim hujan.

\begin{tabular}{|c|c|c|c|c|c|c|c|c|c|}
\hline \multirow{2}{*}{ No } & \multirow{2}{*}{ Jenis } & \multicolumn{3}{|c|}{ Perairan Pantai } & \multicolumn{3}{|c|}{ Perairan Mangrove } & \multicolumn{2}{|c|}{ Catatan Distribusi } \\
\hline & & $\mathbf{b}$ & $\mathbf{j}$ & $\mathbf{a}$ & $\mathbf{b}$ & $\mathbf{j}$ & $\mathbf{a}$ & Geografis & Habitat \\
\hline I & CALANOIDA & & & & & & & & \\
\hline 1 & Undinula vulgaris & 2 & 2 & 0 & 1 & 1 & 0 & IPAt & $\mathrm{O}$ \\
\hline 2 & Cosmocalanus darwini & 2 & 0 & 0 & 1 & 0 & 0 & $\mathrm{I}, \mathrm{P}, \mathrm{At}$ & $\mathrm{O}$ \\
\hline 3 & Canthocalanus pauper & 6 & 4 & 2 & 1 & 1 & 0 & IPAt & $\mathrm{O}$ \\
\hline 4 & Scolecithrix danae & 1 & 0 & 0 & 0 & 0 & 0 & IPAt & $\mathrm{O}$ \\
\hline 5 & Euchaeta concinna & 2 & 1 & 0 & 1 & 0 & 0 & IP & $\mathrm{N}-\mathrm{O}$ \\
\hline 6 & E. marina & 0 & 2 & 0 & 0 & 0 & 0 & IP & $\mathrm{N}-\mathrm{O}$ \\
\hline 7 & Clausocalanus furcatus & 1 & 1 & 0 & 0 & 0 & 0 & IPAt & $\mathrm{N}$ \\
\hline 8 & C. tenuiremis & 0 & 1 & 0 & 0 & 0 & 0 & IPAt & $\mathrm{N}$ \\
\hline 9 & Metacalanus aurivilli & 0 & 0 & 0 & 1 & 1 & 0 & IP & $\mathrm{N}$ \\
\hline 10 & Lucicutia flavicornis & 2 & 0 & 0 & 0 & 0 & 0 & IP & $\mathrm{O}$ \\
\hline 11 & Acartia erythraea & 3 & 2 & 1 & 0 & 0 & 0 & IPAt & E-N \\
\hline 12 & A. pacifica & 2 & 0 & 0 & 0 & 0 & 0 & IPAt & E-N \\
\hline 13 & Acrocalanus gibber & 2 & 1 & 0 & 1 & 1 & 0 & IPAt & $\mathrm{N}$ \\
\hline 14 & Paracalanus aculeatus & 2 & 2 & 1 & 0 & 0 & 0 & IPAt & $\mathrm{N}-\mathrm{O}$ \\
\hline 15 & P. nudus & 1 & 1 & 0 & 0 & 0 & 0 & IP & $\mathrm{N}-\mathrm{O}$ \\
\hline 16 & Parvocalanus crassirostris & 2 & 2 & 1 & 0 & 0 & 0 & IPAt & $\mathrm{N}$ \\
\hline 17 & Centropages calaninus & 1 & 0 & 0 & 0 & 0 & 0 & IP & $\mathrm{O}$ \\
\hline 18 & C. furcatus & 2 & 0 & 0 & 1 & 0 & 0 & IPAt & $\mathrm{N}$ \\
\hline 19 & C. orsini & 7 & 4 & 2 & 1 & 0 & 0 & IP & $\mathrm{N}$ \\
\hline 20 & C. tenuiremis & 0 & 1 & 0 & 1 & 0 & 0 & IP & $\mathrm{N}$ \\
\hline 21 & Candacia bradyi & 2 & 2 & 0 & 1 & 1 & 0 & IP & $\mathrm{N}$ \\
\hline 22 & C. catula & 1 & 0 & 0 & 0 & 0 & 0 & IP & $\mathrm{N}$ \\
\hline 23 & C. curta & 1 & 0 & 0 & 0 & 0 & 0 & IP & $\mathrm{O}$ \\
\hline 24 & C. discaudata & 1 & 1 & 0 & 0 & 0 & 0 & IP & $\mathrm{N}$ \\
\hline 25 & Paracandacia truncata & 1 & 0 & 0 & 0 & 0 & 0 & IPAt & $\mathrm{O}$ \\
\hline 26 & Calanopia elliptica & 1 & 1 & 1 & 0 & 0 & 0 & IP & $\mathrm{N}$ \\
\hline 27 & C. minor & 10 & 5 & 3 & 0 & 0 & 0 & IP & $\mathrm{N}$ \\
\hline 28 & Labidocera acuta & 0 & 2 & 0 & 0 & 1 & 0 & IP & $\mathrm{N}$ \\
\hline 29 & L. laevidentata & 1 & 1 & 0 & 0 & 0 & 0 & IP & $\mathrm{N}$ \\
\hline 30 & L. kroyeri & 2 & 2 & 0 & 0 & 0 & 0 & IP & $\mathrm{N}$ \\
\hline 31 & L. minuta & 0 & 2 & 0 & 0 & 0 & 0 & IP & $\mathrm{N}$ \\
\hline 32 & L. pavo & 2 & 0 & 0 & 0 & 0 & 0 & IP & $\mathrm{N}$ \\
\hline 33 & Pontella fera & 1 & 0 & 0 & 0 & 0 & 0 & IP & $\mathrm{N}$ \\
\hline 34 & P. denticauda* & 35 & 22 & 10 & 1 & 0 & 0 & IP & $\mathrm{N}$ \\
\hline 35 & P. forficula ${ }^{+}$ & 0 & 10 & 0 & 0 & 0 & 0 & Filipina & $\mathrm{N}$ \\
\hline 36 & P. princeps & 1 & 1 & 0 & 0 & 0 & 0 & IP & $\mathrm{N}$ \\
\hline 37 & P. spinipes & 1 & 1 & 0 & 0 & 0 & 0 & IP & $\mathrm{N}-\mathrm{O}$ \\
\hline 38 & P. surrecta & 1 & 1 & 0 & 0 & 0 & 0 & IP & $\mathrm{N}-\mathrm{O}$ \\
\hline 39 & Pontellopsis armata & 2 & 0 & 0 & 0 & 0 & 0 & IP & $\mathrm{N}$ \\
\hline 40 & P. krameria & 1 & 1 & 0 & 0 & 0 & 0 & IP & $\mathrm{N}$ \\
\hline 41 & P. macronyx & 1 & 1 & 0 & 0 & 0 & 0 & IP & $\mathrm{N}$ \\
\hline 42 & P. perspicax & 2 & 2 & 0 & 0 & 0 & 0 & IPAt & $\mathrm{N}-\mathrm{O}$ \\
\hline 43 & P. tenuicauda & 0 & 2 & 0 & 0 & 0 & 0 & IP & $\mathrm{N}$ \\
\hline
\end{tabular}




\begin{tabular}{|c|c|c|c|c|c|c|c|c|c|}
\hline \multirow{2}{*}{ No } & \multirow{2}{*}{ Jenis } & \multicolumn{3}{|c|}{ Perairan Pantai } & \multicolumn{3}{|c|}{ Perairan Mangrove } & \multicolumn{2}{|c|}{ Catatan Distribusi } \\
\hline & & $\mathbf{b}$ & $\mathbf{j}$ & $\mathbf{a}$ & $\mathbf{b}$ & $\mathbf{j}$ & $\mathbf{a}$ & Geografis & Habitat \\
\hline 44 & Pontellina plumata & 2 & 2 & 0 & 1 & 0 & 0 & IP & $\mathrm{N}-\mathrm{O}$ \\
\hline 45 & Pseudodiaptomus incises $^{+}$ & 1 & 1 & 0 & 0 & 0 & 0 & China & E-N \\
\hline 46 & P. clevei & 2 & 1 & 0 & 0 & 0 & 0 & IP & $\mathrm{N}$ \\
\hline 47 & Tortanus forcipatus & 0 & 0 & 0 & 1 & 0 & 0 & IP & $\mathrm{N}$ \\
\hline 48 & T. gracilis & 1 & 1 & 0 & 1 & 0 & 0 & IP & $\mathrm{N}$ \\
\hline 49 & Temora discaudata* & 11 & 8 & 5 & 1 & 0 & 0 & IPAt & $\mathrm{N}$ \\
\hline 50 & T. turbinate & 10 & 7 & 4 & 1 & 0 & 0 & IPAt & $\mathrm{N}$ \\
\hline 51 & Subeucalanus subcrassus & 11 & 5 & 5 & 2 & 0 & 0 & IP & $\mathrm{O}$ \\
\hline 52 & Rhincalanus cornutus & 2 & 1 & 0 & 0 & 0 & 0 & IP & $\mathrm{O}$ \\
\hline II. & CYCLOPOIDA & & & & & & & & \\
\hline 53 & Oithona plumifera & 1 & 0 & 0 & 0 & 0 & 0 & I,P,At & $\mathrm{O}$ \\
\hline 54 & O. tenuis & 2 & 1 & 0 & 0 & 0 & 0 & $\mathrm{I}, \mathrm{P}$ & $\mathrm{N}$ \\
\hline III. & POECILOSTOMATOIDA & & & & & & & & \\
\hline 55 & Oncaea conifera* & 0 & 0 & 0 & 8 & 6 & 0 & $\mathrm{I}, \mathrm{P}$ & $\mathrm{N}$ \\
\hline 56 & O. media & 2 & 1 & 0 & 0 & 0 & 0 & IP & $\mathrm{N}$ \\
\hline 57 & Corycaeus asiaticus & 3 & 2 & 0 & 1 & 0 & 0 & IP & $\mathrm{N}$ \\
\hline 58 & C. andrewsi & 2 & 2 & 0 & 0 & 0 & 0 & IP & $\mathrm{N}$ \\
\hline 59 & C. crassiusculus & 0 & 0 & 0 & 1 & 0 & 0 & IPAt & $\mathrm{O}$ \\
\hline 60 & C. lubbocki & 10 & 5 & 3 & 0 & 0 & 0 & IP & $\mathrm{O}$ \\
\hline 61 & C. pacificus & 1 & 1 & 0 & 0 & 0 & 0 & IP & $\mathrm{N}$ \\
\hline 62 & C. speciosus* & 1 & 0 & 0 & 12 & 8 & 2 & IPAt & $\mathrm{N}$ \\
\hline 63 & Farranula concinna & 2 & 1 & 0 & 0 & 0 & 0 & IP & $\mathrm{N}$ \\
\hline 64 & F. gibbula & 15 & 6 & 2 & 1 & 0 & 0 & IP & $\mathrm{N}$ \\
\hline 65 & Sapphirina sp. & 2 & 0 & 0 & 0 & 0 & 0 & Ns & $\mathrm{N}-\mathrm{O}$ \\
\hline 66 & Copilia mirabilis & 2 & 1 & 0 & 0 & 0 & 0 & IP & $\mathrm{O}$ \\
\hline IV & HARPACTICOIDA & & & & & & & & \\
\hline 67 & Euterpina acutifrons & 2 & 1 & 0 & 0 & 0 & 0 & IPAt & $\mathrm{N}$ \\
\hline 68 & Eudactylopus latipes & 3 & 1 & 0 & 0 & 0 & 0 & IP & $\mathrm{O}$ \\
\hline 69 & Macrosetela gracilis & 3 & 0 & 0 & 0 & 0 & 0 & IPAt & $\mathrm{O}$ \\
\hline 70 & Microsetella rosea & 1 & 0 & 0 & 1 & 0 & 0 & IPAt & E-N \\
\hline V & MONSTRILLOIDA & & & & & & & & \\
\hline 71 & Monstrilla sp. & 2 & 2 & 0 & 0 & 0 & 0 & Undes. & Parasit \\
\hline VI & SIPHONOSTOMATOIDA & & & & & & & & \\
\hline 72 & Caligus sp. & 1 & 0 & 0 & 0 & 0 & 0 & Undes. & Parasit \\
\hline
\end{tabular}

Keterangan: $b=$ betina, $j=$ jantan, dan $a=$ anakan. Catatan sebaran berdasarkan kondisi sebaran geografis: $\mathrm{I}=$ Samudra Hindia, $\mathrm{P}=$ Pasifik, dan At $=$ Atlantik. Catatan sebaran berdasarkan toleransi terhadap salinitas: $\mathrm{O}=$ Oseanik, $\mathrm{N}-\mathrm{O}=$ Neritik-Oseanik, $\mathrm{N}=$ Neritik, $\mathrm{E}-\mathrm{N}=$ Estuarin-Neritik; Undes. $=$ Undescribed species, $*=$ jenis dominan, ${ }^{+}$catatan baru.

Indeks Keanekaragaman Jenis di Habitat Mangrove dan Pantai

Keanekaragaman jenis berdasarkan Indeks Simpson (Tabel 2) di habitat pantai dan mangrove sama-sama tinggi, yaitu 0,9473 dan 0,8345 (dalam rentang $0-1$ ). Namun, jika keanekaragaman jenis di kedua habitat tersebut dibandingkan menggunakan Indeks Shannon (Tabel 2), maka habitat pantai memiliki nilai indeks keanekaragaman yang lebih tinggi, yaitu sekitar 3,584 (68 jenis dari 36 marga dan 23 suku) dibandingkan dengan mangrove sekitar 2,431 (24 jenis dari 18 marga dan 13 suku). Keanekaragaman yang tinggi di kedua lokasi 
Tabel 2. Indeks keanekaragaman pada kedua lokasi

\begin{tabular}{ccc}
\hline & Pantai & Mangrove \\
\hline Taxa_S & 68 & 24 \\
Individuals & 331 & 62 \\
Dominance_D & 0,05271 & 0,1655 \\
Simpson_1-D & 0,9473 & 0,8345 \\
Evenness_e $^{\mathrm{H}} / \mathrm{S}$ & 0,5295 & 0,4736 \\
Chao-1 & 70,64 & 41,14 \\
\hline
\end{tabular}

penelitian ini karena dilakukan pada musim hujan, akibat curah hujan yang tinggi menyebabkan input nutrien yang dibawa oleh air hujan menyuburkan perairan dan populasi fitoplankton sebagai pakan kopepoda juga meningkat. Hal ini sesuai dengan penelitian Arinardi (1978) bahwa Calanoida di Pulau Panggang, Kepulauan Seribu ditemukan dalam jumlah sangat banyak bertepatan dengan atau sesudah curah hujan yang lebat. Sutomo (1978) juga menemukan bahwa jumlah ratarata zooplankton tertinggi di perairan Teluk Jakarta ditemukan pada bulan November (musim peralihan II) dan terendah pada bulan Mei (musim peralihan I).

Kelimpahan kopepoda di pantai (331 individu) lebih besar daripada di mangrove (62 individu). Tingginya kelimpahan jenis kopepoda di perairan pantai disebabkan lokasinya yang memiliki hubungan langsung dengan Samudra Hindia yang memberikan keleluasaan bagi kopepoda oseanik untuk keluar masuk perairan Pantai Panaitan, sedangkan lebih rendahnya kelimpahan yang didapatkan di area mangrove pada penelitian ini mungkin karena mangrove yang tipis atau rusak dan menjadi tempat menumpuknya berbagai jenis sampah, dengan warna air coklat kehitaman, dangkal, dan berlumpur. Menurut Chew \& Chong (2011) puncak kelimpahan kopepoda di mangrove berhubungan erat dengan konsentrasi klorofil yang jatuh ke perairan.

Dominansi jenis pada kedua habitat ada tetapi cukup rendah sekitar 0,05271 di pantai dan 0,1655 di mangrove (dalam rentang 0-1). Pontella denticauda dan Temora discaudata ditemukan mendominasi perairan pantai dengan kelimpahan masing-masing 35b:22j:10a dan 11b:8j:5a, sedangkan di perairan mangrove didominasi oleh Corycaeus speciosus dan Oncaea conifera dengan kelimpahan masing-masing 12b:8j:2a dan 8b:6j:0a. Bentuk dewasa dan anakan P. denticauda dan T. discaudata ditemukan sangat melimpah di perairan pantai terutama pada sampel malam hari, sebaliknya hanya ditemukan masingmasing satu individu betina di perairan mangrove (Tabel 1). Corycaeus speciosus ditemukan satu individu betina di perairan pantai, sedangkan O. conifera tidak ditemukan di perairan pantai. Jika indeks dominansi dibandingkan dengan indeks keanekaragaman Simpson maka terlihat jelas bahwa terdapat korelasi negatif (Odum 1993) di mana meningkatnya indeks keanekaragaman kopepoda maka nilai dominansi menurun dan itu terjadi di perairan pantai (Indeks Simpson $=$ 0,9473). Sebaliknya, menurunnya indeks keanekaragaman, maka dominansi tinggi terjadi di perairan mangrove (Indeks Simpson $=$ 0,8345) (Tabel 2).

Jika nilai Evenness $0<\mathrm{E} \leq 0,5$ maka distribusi individu di komunitas tersebut termasuk kategori rendah (Odum 1993; Marshall \& Baird 2000). Habitat mangrove memiliki nilai indeks kemerataan rendah 0,4736 karena adanya mangrove yang tipis dan perairan dangkal berlumpur dibandingkan dengan habitat pantai dengan nilai evenness $>0,5$ yang merupakan perairan pelagis. Nilai kategori 
Tabel 3. Kisaran suhu dan salinitas perairan pantai Selat Panaitan dan hutan mangrove Pulau Panaitan.

\begin{tabular}{llll}
\hline & Habitat & Suhu & Salinitas \\
\hline 1 & Pantai & $29^{\circ}-31^{\circ} \mathrm{C}$ & $30-32 \mathrm{psu}$ \\
2 & Mangrove & $28^{\circ}-29^{\circ} \mathrm{C}$ & $25-30 \mathrm{psu}$ \\
\hline
\end{tabular}

indeks kemerataan yang rendah pada komunitas ikan koral disebabkan karena adanya kerusakan koral (Ulfa et al. 2019).

Identifikasi keberadaaan jenis sebanyak 68 jenis di habitat pantai hampir mendekati analisis perkiraannya sebanyak 70,64 jenis, sedangkan identifikasi keberadaan 24 jenis di habitat mangrove masih jauh dari perkiraannya sebanyak 41,14 jenis. Hal ini terjadi karena keterbatasan upaya sampling di habitat mangrove yang dangkal dan berlumpur sehingga tidak bisa menggunakan metode vertikal.

\section{Salinitas dan Suhu Perairan Pulau Panaitan dan Kaitannya dengan Dominansi}

Secara umum perairan Pulau Panaitan masih dalam batas toleransi hidup kopepoda (Tabel 3). Dominasi jenis kopepoda neritik (41 jenis) di dua lokasi penelitian berkaitan erat dengan pengaruh massa air dari Samudra Hindia yang cenderung memiliki suhu rendah dan salinitas tinggi, serta sedikit berfluktuasi. Perubahan dan gradien pada salinitas dan suhu diduga merupakan salah satu faktor penting yang memengaruhi sebaran jenis kopepoda yang berbeda di wilayah ini.

Tingginya salinitas di perairan mangrove Pulau Panaitan menyebabkan jenis-jenis kopepoda mangrove tertentu tidak dapat ditemukan, seperti: Acartia sinjiensis dan Acartiella nicolae yang biasanya melimpah di perairan mangrove yang bersalinitas rendah di perairan hutan mangrove Segara Anakan dan Tegal (Mulyadi \& Ishimaru 1994; Mulyadi \& Murniati 2017). Salinitas merupakan faktor pembatas bagi kehidupan Kopepoda. Namun, salinitas yang optimum untuk kehidupan kopepoda belum diketahui secara pasti. Kopepoda dapat hidup di perairan umum pada salinitas 26,5 psu dan 37,6 psu (Levinton 1982) dan lebih khusus untuk kopepoda laut adalah 30-35 psu (Lavens \& Sorgeloos 1996; Marcus \& Wilcox (2007), sedangkan dalam lingkungan kultur dapat bertahan pada air laut bersalinitas 25-30 psu (Lavens \& Sorgeloos 1996).

Selain salinitas, suhu juga merupakan faktor penting. Peningkatan suhu dalam batas optimal dapat mengakibatkan peningkatan metabolisme dan aktivitas reproduksi pada kopepoda (Garcia-Corral et al. 2017; Sandersfield et al. 2016). Menurut Laveng \& Sorgelos (1996) kopepoda tidak mampu mentolerir perubahan suhu yang ekstrim, tetapi mampu hidup pada kondisi yang intensif antara 17-30 ${ }^{\circ} \mathrm{C}$ dengan suhu optimal untuk tumbuh $16-18^{\circ}$ C. Menurut Uye (1980) masa hidup Acartia clausi yang menggunakan lumpur sebagai sedimen mencapai sekitar 100-165 hari dengan suhu $5{ }^{\circ} \mathrm{C}$, dan tanpa sedimen dengan suhu $20{ }^{\circ} \mathrm{C}$ masa hidupnya hanya sekitar 70 75 hari. Salinitas dan suhu air yang mematikan bagi Centropages furcatus dan Euterpina acutifrons betina dewasa adalah di bawah 13,1 psu dan di bawah $26,6{ }^{\circ} \mathrm{C}$ (Umar 2009).

\section{KESIMPULAN}

Sebaran kopepoda perairan Panaitan di dominansi oleh jenis dari Ordo Calanoida dan Ordo Poecilostomatoida. Dua catatan baru, 
yaitu Pontella forficula dan Pseudodiaptomus incisester sebelumnya hanya ditemukan di Filipina dan China. Secara umum keanekaragaman di kedua lokasi tinggi, tetapi apabila keduanya dibandingkan maka keanekaragaman kopepoda perairan pantai jauh lebih tinggi dibandingkan perairan mangrove. Kekayaan jenis kopepoda di pantai yang diperoleh sudah mendekati analisis perkiraannya, tetapi di mangrove masih sangat jauh karena berdasarkan pengamatan di lapangan, tumbuhan mangrove di Pulau Panaitan sudah tipis atau rusak yang menyebabkan lebih rendahnya kekayaan jenis yang didapat jika dibandingkan dengan di pantai, serta kondisi substrat berlumpur yang menyebabkan keterbatasan upaya pengambilan sampel di penelitian ini. Faktor lingkungan Pulau Panaitan bersuhu rendah dan bersalinitas tinggi menyebabkan dominansi perairan oleh kopepoda tipe neritik.

\section{UCAPAN TERIMA KASIH}

Penelitian ini dibiayai oleh Anggaran DIPA Puslit Biologi LIPI tahun 2009 dan kerja sama LIPI-JSPS dalam program penelitian yang berjudul Biodiversity and Ecological Roles of Jellyfishes and Ctenophore in Indonesian Waters pada tahun 2008-2010. Penulis mengucapkan terima kasih kepada petugas Pulau Panaitan T.N. Ujung Kulon, Banten yang telah membantu selama penelitian di lapangan.

\section{DAFTAR PUSTAKA}

Arinardi, O. H. (1978). Seasonal variations of certain major zooplankton groups around Panggang Island, north-west off Jakarta. Marine Research Indonesia, 21, 61-80.

Buzas, M. A. \& T G. Gibson. (1969). Species diversity: benthonic foraminifera in western north Atlantic. Science, 163, 72-75.

Chao, A. (1984). Nonparametric estimation of the number of classes in a population. Sand. J. Statist., 11,265-270.

Chew, L. L. \& Chong, V. C. (2011). Copepod community structure and abundance in a tropical mangrove estuary, with comparisons to coastal waters. Hydrobiologia, 666, 127-143.

Dussart, B. H. (1985). Une Acartiella (Copepode, Calanoide) a Borneo. Crustaceana, 49(1), 49-51.

Garcia-Corral, L. S., Holding, J. M., Carrillode-Albornoz, P., Steckbauer A., Pérez -Lorenzo M., Navarro, N., Serret, Pablo, Gasol, J. M., Morán, X. A. G., Estrada, M, Fraile-Nuez, E., BenítezBarrios, V., Agusti, S, \& Duarte, C. M. (2017). Temperature dependence of plankton community metabolismin the subtropical and tropical oceans. Global Biogeochem. Cycles, 31, 11411154. http://x.doi.org/10.1002/2017GB005629.

Hammer, Ø. H., David, A.T., \& Paul, D. R. (2001). Past: paleontological statistics software package for education and data analysis. Palaeontologia Electronica, 4(1), art. 4: 9pp.

Huys, R. \& Boxshall, G. A. (1991). Copepod evolution. Ray Society London, 468 pp.

Kim, D. Y. (1985). Taxonomical study on Calanoid copepod (Crustacea: Copepoda) in Korean waters. PhD Thesis, Hanyang Univ. 187 pp, 50 pls.

Lavens, P. \& Sorgeloos, P. (1996). Manual of the production and use of live food for aquaculture. FAO Fisheries Tch. 
Paper no. 31. Rome.

Levinton, J. S. (1982). Marine ecology. PrenticeHall Inc. Englewood Cliffs. New Jersey.

Madhupratap, M. \& Haridas, P. (1986). Epipelagic calanoid copepods of the northern Indian ocean. Oceanologia Acta, 9(2), 105-117.

Marcus, N. H. \& Wilcox, J. A. (2007). A guide to the meso-scale production of the copepod Acartia tonsa. Florida Sea Grant. [Online]. Diambil dari http://nsgl.gso.uri.edu/flsgp/flsgph07002. pdf. [25 April 2021].

Marshall, P. A. \& Baird, A. H. (2000). Bleaching of corals on the Great Barrier Reef: differential susceptibilities among taxa. Coral Reef, 19, 15-163.

Mori, T. (1937). The pelagic Copepoda from the neighbouring waters of Japan. Soyo Company Inc. Tokyo.

Mulyadi \& Ishimaru, T. (1994). Species composition of copepods in the Cilacap mangrove estuary, Central Java, Indonesia. In: Ecological assessment for management planning of Segara Anakan Lagoon, Cilacap, Central Java (Eds. Takashima, F. \& K. Soewardi). NODAI Center for International Program Tokyo University of Agriculture JSPS-DGHF Program, 3947.

Mulyadi. (1997). Three new species of Pontellidae (Copepoda: Calanoida) from coastal waters of Java, Indonesia. Crustaceana, 70 (6), 653-675.

Mulyadi. (2002). The calanoid copepods family Pontellidae from Indonesian waters, with notes on its species-groups. Treubia, 32(2), 167 pp., 60 figs.

Mulyadi. (2003). Three new species of Pontella (Copepoda: Calanoida) from Indonesian waters, with notes on their species groups. Crustaceana, 76(4), 385-402.

Mulyadi. (2004). Calanoid copepods in Indonesian waters. Research Center for Biology, Indonesian Institute of Sciences, Bogor, Indonesia, 195 pp. 107 figs.

Mulyadi \& Mumiati, D. C. (2017). Keanekaragaman, kelimpahan, dan sebaran kopepoda (krustasea) di perairan bakau Segara Anakan, Cilacap. OLDI, 2(2), 21-31.

Nurdin, S., Rafianti, \& Mandaputra, R. (1998). Kondisi kopepoda pada hutan mangrove di daerah pendangkalan muara Sungai Rokan, Bagan Siapi-api, Riau. Pros. Sem. VI Ekosistem Mangrove, 215524.

Nybakken, J. W. (1982). Biologi laut: suatu pendekatan ekologis. Jakarta: PT Gramedia, 445 hal.

Odum, E. P. (1993). Dasar-dasar ekologi. Edisi Ketiga. Diterjermahkan oleh T. Samingan. Gadjah Mada Universitas Press. Yogyakarta. 697 p.

Rahayu, S., Setyawati, T. R., \& Turnip, M. (2013). Struktur komunitas zooplankton di muara Sungai Mempawah, Kabupaten Pontianak berdasarkan pasang surut air laut. Protobiont, 2(2), 49-55.

Sandersfeld, T., Davison, W., Lamare, M. D., Knust, R., \& Richter, C. (2016). Elevated temperature causes metabolic trade-offs at the whole-organism level in the Antarctic fish Trematomus bernacchii. PANGAEA. Journal of Experimental Biology, 218(15), 23732381. https://doi.org/10.1594/PANGAEA. 858520 .

Saputra, A., Lestari, E., \& Hadisusanto, S. (2012). Komposisi dan kemelimpahan zooplanton di Laguna Glagah Kabupaten 
Kulonprogo Provinsi Daerah Istimewa Yogyakarta. Seminar Nasional X Pendidikan Biologi FKIP UNS.

Scott, A. (1909). The copepod of the Siboga Expedition. Part I. Free-swimming, littoral and semi-parasitic Copepoda. Siboga Exped. Monografieen, 29a, 1323, 1-69 pls.

Shannon, C. E. (1948). A mathematical theory of communication. The Bell System Technical Journal, 27, 379-423.

Simpson, E. H. (1949). Measurement of diversity. Nature, 163, 688. https://doi.org/10.1038/ $163688 \mathrm{a} 0$.

Sutomo, A. B. (1978). Sebaran zooplankton di perairan Teluk Jakarta dan sekitarnya Mei 1978. Pemonitoran Teluk Jakarta. Laporan No. 11. Palayaran KM Samudra 19-22 Mei 1978. Lembaga Oseanologi Nasional LIPI: 67-71.

Sutomo, A. B. (2003). Pengaruh salinitas dan jenis mikroalga (Chaetoceros gracilis dan Nannochloropsis oculata) terhadap perkembangan nuplii dan pertumbuhan kopepoda (Tigriopsis brevicornis). OLDI, 38, 47-67.

Tranter, D. J. \& Abraham, S. (1971). Coexistence of species of Acartiidae (Copepoda) in the Cochin backwater, amonsoonal estuarine lagoon. Mar. Biol., 11, 222-2241.

Ulfah, M., Fajri, S. N., Nasir M., Hamsah, K.,
\& Purnawan, S. (2019). Diversity, evenness and dominance index reef fish in Krueng Raya Water, Aceh Besar. IOP Conf. Ser.: Earth Environ. Sci. 348012074.

Umar, N. A. (2009). Dinamika populasi plankton dalam area pusat penangkapan benur dan nener di perairan pantai Kecamanatan Suppa Kabupaten Pinrang, Sulawesi Selatan. Disertasi Parcasarjana Prodi Ilmu Kelautan IPB. IPB: Bogor.

Uye, S. (1980a). Development of neritic copepodids Acartia clausi and A. steueri I. Some environmental factors affecting egg development and the nature of resting eggs. Bull. Plankton Soc. Japan, 27, $1-9$.

Uye, S. (1980b). Development of neritic copepodids Acartia clausi and A. steueri II. Isochronal larval development of various temperatures. Bull. Plankton Soc. Japan, 27 (1): 1118.

Wellerhaus, S. (1969). On the taxonomy of planktonic Copepoda in the Cochin Backwater (A South Indian Estuary). Veroff. Inst. Meeresforrsch, Bremerh., 11, 245-286.

Yuniar, A. T., Palm, H., \& Walter, T. (2007). Crustacean fish parasites from Segara Anakan Lagoon, Java, Indonesia. Parasitol. Res., 100, 1193-11204. 